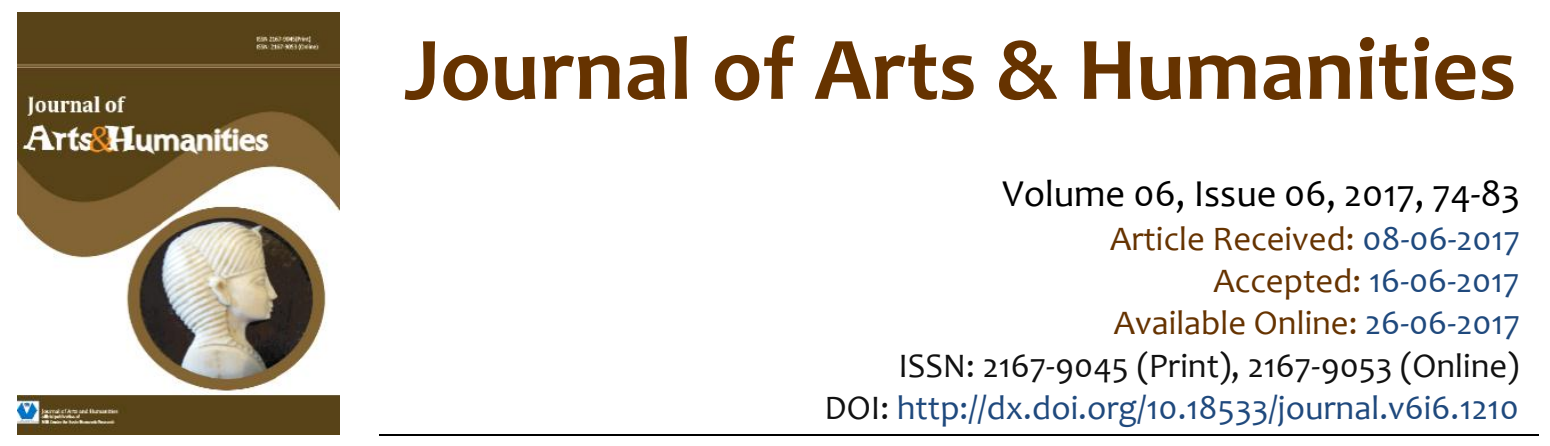

\title{
University Involvement with Charter Schools: Unique Opportunities for Service and Support
}

\author{
Julie Hentges, Ed. D. ${ }^{1}$, Doug D. Thomas, Ed. D. ${ }^{2}$
}

\begin{abstract}
Charter schools are a controversial, but vibrant, component of the current educational landscape, now serving over 3.1 million students in approximately 6900 schools across the United States. A unique aspect of this undertaking has been the establishment of alternative authorizers, and specifically universities, to approve and provide oversight to these public schools. Campus leaders and policy makers must contemplate numerous variables regarding a university's involvement with the charter school movement. What types of support should a university provide to a school it authorizes? What support is most beneficial, and how do we know? Can universities provide the required "oversight" mandated by the charter school laws, as well as providing "support" for the schools? What opportunities for partnerships should exist? Do charters provide avenues for traditional higher education roles of teaching, service, and research? With 18 years of experiences as a public university on the forefront of enabling charter legislation and the "sponsorship" of innercity public charter schools, the authors provide a historical perspective of the role of university partnerships within the school choice initiative. This article provides an overview of issues that arise with public charter schools authorized by universities. We conclude by outlining successful oversight roles and supportive programs within the unique and growing phenomenon of school choice.
\end{abstract}

Keywords: Charter schools, University partnerships, Charter school authorizers, Oversight.

JEL codes: 1200, 1210, 1230, 1280.

This is an open access article under Creative Commons Attribution 4.0 License.

\section{Introduction}

Charter schools have become a significant part of American education. Currently, over 6500 charter schools are serving approximately 3.1 million students across our nation (National Alliance for Public Charter Schools, 2017). As an alternative to traditional public schools and a key component of the school choice movement, the debate over charter schools "has become increasingly heated" (Malkus,

\footnotetext{
${ }^{1}$ Associate Professor, Elementary \& Early Childhood Education, University of Central Missouri, Warrensburg, MO, USA E-mail: hentges@ucmo.edu

2 Professor, Educational Leadership, University of Central Missouri, Warrensburg, MO, USA E-mail: thomas@ucmo.edu
} 
2016, p. 479). Charter schools begin as an alternative to neighborhood school attendance. "The emergence of charter schools, which, when first introduced in 1991, came with two distinct promises: to serve as an escape hatch for students in failing schools, and to create and incubate new educational practices" (Fryer, 2012, p. 2).With the charter school initiative parents are provided with school choice.

The University of Central Missouri has been an authorizer of public charter schools for over 18 years. Appearing on the forefront of supporting charter legislation sponsoring inner-city school initiatives affords the University of Central Missouri to offer a sound historical stance of the university's involvement within the school choice movement. Soon after the Missouri charter legislation was passed in 1998, the University of Central Missouri undertook an extensive review to create a welldefined role as a potential authorizer of public charter schools.

Several factors are important in understanding a university's decision to become an authorizer of charter schools. Garcia and Morales (2016) offered, "authorizing practices (can be) shaped by external factors, the agency of the actors within the authorizing office, and by the local context in which the authorizer was situated" (p. 495). For the University of Central Missouri, this decision was influenced by a number of key issues, including (1) compatibility with university and college mission; (2) legislative intent; and (3) perceived liability to the university (Thomas \& Machell, 2001, p. 9). The review determined that sponsorship (authorization) of public charter schools was aligned with the University's mission, including key functions such as providing service, improving teacher preparation, improving urban education, and teacher recruitment. Stemming from these philosophical underpinnings, the University of Central Missouri set about to determine effective levels of oversight and support for the charter schools operating under its sponsorship.

\section{Methodology}

This study is quantitative in nature, stemming from a historical analysis of one university's role within the school choice movement. The purpose of this type of study is to provide holistic insights based upon focused observations and institutional artifacts. The University of Central Missouri has been an authorizer of public charter schools for over 18 years, providing a rich history of practices and processes that have evolved over time. The researchers have served as active participants within this setting. The descriptive study is "ethnographic" in nature, as it involves the analysis of what occurred within the University and the charter schools operating under its sponsorship over a period of time.

\section{Significance of the study}

Gustafson (2013) states charter schools "have been a focus of school reform advocates and the subject of substantial research. Yet the regulators of the charter industry (called "authorizers" or "sponsors") remain a mystery to many" (p.33). Because "the authorizing environment can directly determine whether the charter seats that are created and maintained are of high quality" (p. 33), it is important to determine an effective authorizing environment. Gustafson (2013) states, "While authorizers are not the operators, they set the standards and measure operators against those standards. The work of authorizers is central to the charter compact: granting autonomy in exchange for accountability" (p.33).

According to the National Association of Charter School Authorizers (NACSA, 2015), authorizers are charged to: 1. Maintain high standards; 2. Uphold school autonomy; and 3. Protect student and public interests. As evidenced by student success, there are five components which consistently appear as charter schools' indicators of success (National Alliance for Public Charter Schools, 2009).

- Supportive laws and regulations (both what is on the books and how it is implemented);

- Quality authorizers;

- Effective charter support organizations, such as state charter associations and resource centers; 
- Outstanding school leaders and teachers; and,

- Engaged and community members (pg 1-2).

Clearly, these are significant gate-keeping responsibilities on the part of the sponsor/authorizer.

Herein resides a key issue for charter schools--adequate oversight of the schools by their sponsors. Authorizers ensure that the schools are operating as per the charter agreement and fulfilling its missions. However, as noted by Goenner (2004), although authorizers play a critical role in helping establish charter schools, they do not own or operate them.

"Few issues provoke as much debate as charter schools, which are publicly funded schools... and are under the authority of a quasi-contract, or "charter," granted by a public body" (Buddin \& Zimmer, 2005, p.351). Although it may be difficult to simplify charter school issues, the fact is, to remain viable charter schools need to "persuade an (charter) authorizer to re-charter them every few years" (Hoxby \& Rockoff , 2005, p. 52). The act of persuading includes providing solid documented evidence of student success. Many factors are considered as measures of success for a charter school, state assessments are recognized as a major gage of the schools' achievement. These tests are "consistently used by parents, policymakers, and the general public as key indicators for performance" (Buddin \& Zimmer, 2005, p. 360). The attention to supporting students in high-risk environments to excel can be a daunting task. "Because of the tremendous variation among charter schools in terms of size, structure, mission, and a host of other variables, it is very difficult to make any sort of useful, categorical generalizations about them" (Virtue, 2012, p. 5).

University support provided to schools it authorizes brings into play a number of policy, procedural, and ethical issues to consider.

- What types of support should a university provide to a school it authorizes?

- What type of relationships or partnerships should exist?

- What are the implications of a university's support for charter schools with key stakeholders, not only at the charter schools, but with traditional university stakeholders as well, such as area public school leaders, university funders, and faculty?

- How can an authorizer help charter school administrators and faculty to view university involvement as advantageous?

This article examines these inquiries of university involvement with public charter schools.

\section{Key findings}

The University of Central Missouri provides a unique perspective of the university's commitment to the charter school movement. Several factors are important in understanding a university's decision to become an authorizer of charter schools.

For the University of Central Missouri, this decision was influenced by a number of key issues, including (1) compatibility with university and college mission; (2) legislative intent; and (3) perceived liability to the university (Thomas \& Machell, 2001, p. 9).

Soon after the Missouri charter legislation was passed in 1998, the University of Central Missouri undertook a broad review of its potential role as an authorizer of public charter schools. Only after the University of Central Missouri completed a wide-ranging review was it determined to take on the charge of sponsorship (authorization) of public charter schools. There was evidence that participating in the charter school movement aligned clearly with the University's mission of providing service, improving teacher preparation, improving urban education, and teacher recruitment (Thomas \& Machell, 2001). It was at that point, the University of Central Missouri decided to establish oversight support for charter schools. 


\section{1 Charter school oversight}

In compliance with statutory requirements and its own policies, the University of Central Missouri (UCM) oversight processes have developed over time. Currently, the College of Education houses the Charter School Office which is staffed by a Director, field representative, consultants and an office professional. Sponsorship costs are defrayed with a portion (1.5\%) of the per-student funding sent to the charter school authorizer (defined as the "sponsor" in Missouri legislation). The sponsor must then expend a minimum of $90 \%$ of its charter school sponsorship funds in support of its charter school sponsorship program, or as a direct investment in the sponsored schools (DESE, 2017).

On-site evaluations and program assessments are conducted throughout the year. A calendar of oversight topics is maintained, outlining the timing and scope of the oversight activities. The oversight process often involves the collection of compliance reporting documents, such as teacher certification reports and state financial documents. Other items involve scheduled site visits to the schools for specific program assessments. Specific oversight site reviews include 1) academic programs and accountability, 2) safety and facility issues, 3) governance, 4) fiscal reporting and accountability, 5) personnel and payroll, 6) certification, 7) student records, 8) curriculum review and 9) professional development. In support of these oversight roles, University personnel participate in state level and area meetings of charter school sponsors, attend national, state, and local meetings focusing on charter schools, and participate in leadership meetings stemming from the Dean's office and departments within the College of Education. Oversight activities are conducted throughout the year; with the primary functions regarding charter school oversight embedded in the series of operational reviews conducted at the school site.

To foster positive communication channels between the University and charter operators, monthly meetings are organized throughout the year. Administrators from the nine charter schools currently sponsored by the University participate in the monthly meetings. Oversight issues are on the agenda for discussion and input from the charter school administrators. Additionally, the charter school administration will receive notification from the Charter School Office outlining the specific date of an upcoming visit by staff or consultants and a list of documents the school will need to have available for reference.

Oversight team members often include faculty selected from various academic disciplines that align with their respective responsibility. For example faculty from the School Administration program has been contracted to provide fiscal, governance, and board policy reviews. Other College of Education faculty members have provided assessments of curriculum, professional development, and academic accountability. Charter school oversight members are charged with serious and significant responsibilities. They closely examine key processes related to the continuation of a charter agreement. After the conclusion of the visit, a composite report is submitted to the Charter Schools Office. Any discrepancies or weaknesses outlined in the report are discussed with the Director. The reports are shared with the school administrators and the governing board of the school. If deficiencies are noted, the report could trigger a series of possible consequences, including action steps for program improvement, or for more serious issues the school could be placed on probationary status. Follow up documentation and subsequent reviews are conducted as warranted.

The reports are filed and reviewed year to year, noting previous concerns, progress in addressing the concerns, or the continuation of noted issues. These reports are also used during the charter renewal process. Charter agreements run for five years, and at the end of the term of the agreement, the University must decide if it wants to continue sponsorship of a school by either renewing or nonrenewing the agreement. During its 18 years as a charter school sponsor, the University has opened 14 schools and closed four of these schools for a variety of reasons, including poor academic performance, poor operations, and fiscal management issues. While it is not the focus of this paper to get into the nuts and bolts or the consequences of the renewal process, it is important to note that this high-stakes process must be supported with effective operational reviews and quantifying data. 
Charter school oversight represents an important quality assurance role for sponsoring agencies. Members of the UCM oversight teams hold high-levels of expertise for the role they serve. The on-site activities of the members involve detailed and meticulous work that requires patience, skill and a willingness to prepare a report with integrity. Members of the team understand the nature of the work involved and the magnitude of the responsibility associated with the oversight of public charter schools.

There are also clear benefits to university staff participating within the charter oversight processes. Members of the oversight team have an opportunity to expand their knowledge of urban education, observe various approaches to delivering instruction to students, as well as stay up to date on certification, personnel, special education, school law, and other school related issues. Most importantly, university personnel have firsthand professional experiences within the school choice arena.

\subsection{Charter school support and partnerships}

As opportunities were studied, the emphasis was on investing time, expertise, and resources as support for charter schools in a manner that would best serve both the missions of the public charter schools, the service mission of the University, and the statutory mandate for effective oversight. Significant to this initiative was the University's involvement as a level of support as a sponsor of the schools but more importantly to assist educators and the students they serve. (Thomas \& Machell, 2001).

There was a need to determine what exactly charter school personnel believed would be the most appropriate level of support. Should university consultants help support teachers to promote innovative instructional strategies? Would it be appropriate for a consultant to observe teacher and student interactions? Could university consultants provide instructional feedback to the in-service teacher? Would it be appropriate to provide early childhood reading readiness workshops for parents and preschool teachers in the charter school setting? Charter school administration and University leaders determined these levels of support would be well received by charter school personnel.

Secondly, there was a need to determine what type of networking opportunities for university students, staff, and faculty would be appropriate for the charter school educators and governance personnel. Would it be applicable to place university teacher candidates in the field in charter schools to support undergraduates' interests? Should undergraduate students be required to participate in an urban field placement? Could these university students be included in volunteer service opportunities? What about graduate level courses? Would it be appropriate to offer job-embedded elementary education graduate level degree program on a charter school site? What about an administrative graduate level degree? Could a cohort be created to address this initiative? Would it be appropriate for university consultants to participate in charter school improvement programs such as reading/literacy, math, and behavior interventions? With the support of the Director of the Charter School Office and the Dean of the College of Education, it was determined it would be appropriate to provide university instructional staff and consultants from the Regional Professional Development Office and the College of Education in support of these charter school initiatives.

Substantial partnerships and charter school initiatives have developed as a by-product of the University's role as a charter school authorizer. A strong collaborative relationship has been developed and maintained. University instructional staff and consultants started the collaborative process with great anticipation and enthusiasm. Everything about the opportunity suggested the experience would be meaningful to the instructors and consultants. Specific results of the numerous collaborative initiatives have been shown to support powerful and meaningful institutional and professional relationships. 
The UCM partnerships with its charter school stakeholders provide clear evidence toward student achievement and governance goals. Collaborative initiatives to support inner-city charter schools flourished in a variety of ways and within a variety of programs. The University of Central Missouri representatives' levels of support began with a needs analysis. During charter school leadership meetings held in conjunction with the UCM Charter School Office, charter school leadership requested support in areas of strategic needs. Professional development, beginning teacher mentoring, leadership preparation program, governing board training, and partnerships with community service agencies were implemented as levels of support for charter schools. Each of these areas of focus has been addressed. The professional development focus was addressed through the UCM Charter School Office, the RPDC, and UCM College of Education consultants. Charter schools were offered through the direction of the UCM Charter School Office opportunities to participate in levels of support. The following section provides an overview of a few of the key opportunities.

Beginning Teacher Mentoring. The beginning teacher induction and mentoring opportunities were offered through the UCM Charter School Office. This level of support was organized and presented through the Regional and Professional Development Office. Beginning teachers at charter schools were asked to participate on a voluntary basis. These new teachers met with their mentor teachers on a monthly basis. During these sessions, a facilitator offered support to include collaborative opportunities to their learning communities. Documentation was collected throughout the two-year program. The data from this initiative was very positive. As a result of the feedback, this project has continued for several years.

Leadership Collaboration. Leadership support was offered through the direction of the Charter School Office. This level of support was organized through the College of Education consultants, instructors, and facilitators. This initiative includes an opportunity for charter school leaders to meet collectively to address issues which impact inner-city students. The feedback from this collaborative initiative was positive. This initiative has been well received by the charter school leaders.

Governance Support. From the onset of charter school operations, governance was perceived as an area of need by local and state policy makers. To address this need, UCM partnered with other sponsoring institutions to provide training for members of the different governing boards. Support for effective governance of the charter schools has transitioned over the years, moving from large group in-services to individual board training sessions, to strategic planning facilitation. The training sessions were well received and continue to be an important level of support for UCM charter schools.

Community Partnerships. Many community service agencies have expressed an interest in supporting inner-city schools and urban education initiatives. Through the direction and support of the UCM Charter School Office and in collaboration with the College of Education, volunteers have been enlisted to support the charter schools in a number of ways. Where charter schools expressed an interest they have received many volunteer hours from community organizations (i.e. the Mad Scientist) and student volunteers (Elementary and Early Childhood education majors) to engage students in the learning process.

Additionally, UCM has been able to build strong connections with community service organizations in Kansas City who are associated with the schools, such as the Guadalupe Center, Della Lamb Community Services, and Don Bosco Centers. These, and other, community service organizations have been providing support to needy neighborhoods for many years. The charter legislation allowed them to extend this support into public education opportunities serving historically underserved populations. Subsequently, charter sponsorship brought the University in direct contact with key stakeholders within these different services organizations.

Urban Field Experiences. Early in its sponsoring tenure, UCM received a grant from the Hall Family Foundations (Hallmark Cards) to support field experiences to the urban charter schools, providing funding for transportation and a program coordinator. Following the grant, UCM has continued to 
provide field experiences for its education majors, requiring urban, suburban, and rural experiences for all its degree completers. The charter schools provide the primary source of urban field experiences for UCM education majors. Faculty members accompany the undergraduate students in the field experiences, spending the day at an urban site, shadowing students and interacting with urban educators. Personnel from the Charter School Office assist with organizing the trips, provide orientations to the students and faculty, and conduct follow-up evaluations of the urban field experiences.

Research Opportunities. Urban education, and especially the school choice arena, is ripe with research opportunities. The first major research project involving the UCM faculty and the charter schools was a collaborative venture with faculty members pairing up with charter school operators to document the initial year of charter school operations (Sluder, Thomas, \& Snyder, 2001). This collaborative effort resulted in a comprehensive book documenting key events of each school's inception and the first year of operations as a public charter school. Subsequent research projects have led to publications as well as numerous national and international presentations on charter school issues, including oversight, academic programs, growth measures, leadership studies, global patterns of school choice, resegregation trends, and charter schools designed to serve refugee and immigrant students.

Graduate Degree Programs. The University of Central Missouri, in partnership with its public charter schools in Kansas City, has completed two different program providing degrees and/or coursework to charter school educators. UCM has provided courses for cohorts of graduate students participating in an urban leadership preparation program. The urban leadership program was developed to better prepare future school leaders for the unique demands of urban education. All coursework and activities are relevant and meaningful to the leadership and management of urban schools. "Job-embedded" activities are incorporated throughout the coursework to give students the opportunity to work with "real world" situations and issues. Additionally, only instructors with urban experience and expertise, including practitioners from urban districts, were selected to teach the courses. The cohort model provided flexibility and support for the students. Scheduling and advisement were built into the model, bringing these services to the students.

The program was made possible by a number of partnerships between the charter schools, the College of Education, the Graduate School, and the Charter Schools Office. School leaders were vital in the recruitment and selection of students for the program. Additionally, selected school leaders have participated as "guest lecturers" to share their expertise and experiences. Students also receive financial support. The Charter Schools Office provided "tuition" for four of the required classes, basically "reinvesting" a portion of the funds generated by charter school enrollment back to the schools. These courses were designed to support the school improvement mandates embedded in the charter school concept. Fourteen students, all urban educators working at a UCM sponsored charter school, completed the program in 2012. The second cohort of 13 charter school educators completed the program in 2015.

An additional initiative was an Elementary Education Master's Degree cohort designed specifically to meet the needs of the urban educator. Classes were completed at the charter school site for participating teachers. Faculty served dual roles, providing mentoring and consultation during the school day, and serving as an instructor for several of the courses during the degree program. This charter school initiative was a win-win experience for all. The University was offered an exceptional opportunity to interact at a school site to provide graduate level course work which provided on-site benefits to elementary age students in an urban setting. University undergraduate students were allowed a solid field experience of what it might be like to teach and support the individual learning needs of students in an inner-city setting. Unique to the circumstance was the opportunity for university and charter school staff to collaborate and reflect on best practice to promote student learning and achievement in a very authentic and powerful way. Charter school teachers were offered an opportunity to meet face-to-face with their graduate level instructors throughout the instructional day. The job-embedded approach to graduate level coursework offered the graduate students the 
experience and support of going deeper and richer with instruction through collaborative coaching and reflecting instructional experiences.

\section{Recommendations}

Stemming from the findings of this study, the authors forward the following recommendations regarding policies and practices associated with the authorization of public charter schools by institutions of higher education.

- First and foremost, a university should determine if the authorization of charter schools is aligned with, and supported by, its mission. Charter schools often bring highly emotional and political sensitive issues to the university setting, requiring tough decisions and sensitive interactions with state and community stakeholders. Having a strong alignment with the university mission will guide policy development and decision making. It will also frame potential roles for institutional support, faculty involvement, and community partnerships.

- It is essential that the university develop written policies and procedures clearly articulating its roles and responsibilities, as well as its operating procedures. Policies should clearly differentiate institutional roles, such as oversight and support services. Policies should also clearly define potential roles of faculty and support staff.

- University faculty should consider the rich research environment within the school choice educational arena. Key research topics could include the effect of choice on the overall educational status of a community, effective and ineffective charter schools, teacher and school leader preparation issues, charter school demographics, school funding issues, and the re-segregation of schools.

- University personnel should examine grant opportunities with charter school. As both schools of choice and schools often designed to serve high risk student populations, charter school provide ample opportunities for grant funded initiatives.

- Colleges of education should examine the unique needs of educator within the school choice environment and adjust their teacher preparation and leader preparation programs accordingly.

\section{Discussion and conclusions}

The Center for Research on Education Outcomes (2015) offered, "successful charter schools are growing in number and expand the evidence base that schools and communities can organize and operate public schools that deliver the academic progress their students need to be successful in school, work, and life" (p. 7). University authorizers are in a unique position to hold charters accountable for student success while at the same time providing levels of support to these charters. Students at-risk of failure in the public school system include children who are in poverty - "the correlations are consistent with the expressed mission of many urban charter school operators to provide high-quality education choices specifically for these students" (p. 43). The main focus to maintain charter status must be to provide quality school choice options to students who may without this option fail in the public school system. There are evidence successful charter schools follow a similar path. University authorizers can guide charter schools on this path through a collaborative partnership to advocate for student success.

Fryer states, "it is not possible to offer a one-size-fits-all package of reform" (2012, p. 16). So, we must determine effective levels of support depending upon the unique circumstances of each charter program. Once that is determined, we should be "expanding what we know works and conducting more research as we expand those practices" in an effort to "benefit millions of students from the nation's struggling schools and neighborhoods" (Fryer, 2012, p. 16). The collaborative opportunities available are limitless when university partnership and charter school initiatives unite to create a strong learning environment where the instructional needs of the at-risk students are at the forefront of every decision made during the collaborative focus. "The magnitude of the problems in our education system 
is enormous, but (there is) preliminary evidence (which) points to a path forward to save the 3 million students in our nation's worst-performing schools" (Fryer, 2012, p. 16). Many charter schools are eager to move forward on just such a path to "experiment, refine, and develop best practices in education" (CREDO, 2015, p. 38). Students who are considered at-risk can and do achieve when "given the opportunity" (p. 38).

The UCM partnerships with its charter schools have provided clear evidence of effective levels of support and beneficial partnerships. Collaborative initiatives to support inner-city charter schools were implemented and maintained. The University of Central Missouri representatives' levels of support began with a needs analysis. Growing from meetings held in conjunction with the UCM Charter School Office, charter school leadership requested areas of strategic support. Professional development, beginning teacher mentoring, leadership preparation program, governing board training, and partnerships with community service agencies were organized as effective supports for charter schools.

As noted earlier, the UCM community determined involvement with the charter schools was aligned with its mission, including the need to support the schools, and specifically the educators and students they serve (Thomas \& Machell, 2001). If teachers in urban schools determine their success as a teacher by "perceptions of student conduct, support dealing with behavior, and their school's behavioral expectations" (Torres, 2016, p. 177), then, it is imperative they receive support in these areas to remain in the teaching profession. As opportunities were examined, levels of support were considered. The emphasis was on investing time, expertise, and resources as support for these charter schools. Monitoring this focus was an important aspect of the University's mission for service; commitment to provide support to the public charter schools, while following the statutory mandate for effective oversight. "Crucial to this discussion is the charter authorizing process", (Zimmer, 2014, p. 59). Although university authorizers vary nationwide, they are in a perfect position to collaborate with charter schools to champion these opportunities in the best interest of our nation's youth.

\section{References}

Buddin, R.\& Zimmer, R. (2005). Student achievement in charter schools: A complex picture. Journal of Policy Analysis and Management, 24(2), 351-371. Retrieved from https://login.cyrano.ucmo.edu/ login?url=http://search.proquest.com/docview/222449798?accountid=614e3

Center for Research on Education Outcomes (CREDO) (2015) Urban charter school study: Report on 41 regions. Stanford University. Retrieved from https:/urbancharters.stanford.edu/download/ Urban\%20Charter\%20School\%20Study\%20Report\%200n\%2041\%20Regions.pdf

Fryer, R. G., Jr. (2012). Learning from the successes and failures of charter schools. The Hamilton Project, 1-18. Retrieved from olar.harvhttps://schard.edu/files/fryer/files/hamilton_project_paper 2012.pdf

Garcia, P. K., \& Morales, P.Z. (2016). Scaling up success for English language learners in charter schools: Exploring the role of charter school authorizers. Journal of School Choice, 10(4), 495-515. doi.1080/15582159.2016.1238279.

Goenner, J. (2012). Michigan's chartering strategy. Education Next, 12(3) Retrieved from https://login.cyrano.ucmo.edu/login?url=http://search.proquest.com/docview/1237864315?accounti $\mathrm{d}=6143$

Goenner, J. (2004) Charter school oversight: Higher ed's role, School Business Affairs, July/August 2004, pp 17-19. Retrieved from http://www.cmucso.org/modules.php?name=Documents\&op=viewlive \&sp_id $=62$

Gustafson, J. (2013). Charter authorizers face challenges. Education Next,13(3). 33-37. Retrieved from http://educationnext.org/charter-authorizers-face-challenges/

Hoxby, C.M. \& Rockoff, J.E. (2005). Findings from the city of big shoulders. Education Next, 5(4), 52-58 Retrieved from https://login.cyrano.ucmo.edu/login?url=http://search.proquest.com/docview/ 1237806730 ?accountid $=613$ 
Malkus, N. (2016). Seeing charters differently: A new approach to national comparisons of charter and traditional public schools. Journal of School Choice,10(4), 479-494. doi:10.1080/15582159.2016.1238737

Missouri Department of Elementary and Secondary Education (DESE), (2017). Frequently asked questions: Charter schools, retrived from https://dese.mo.gov/faqs/charter\%20schools

National Alliance for Public Charter Schools (2009), A new model law for supporting the growth of highquality public charter schools, retrieved from http://www.publiccharters.org/wpcontent/uploads/2014/01/ModelLaw_P7-wCVR_20110402T222341.pdf

National Alliance for Public Charter Schools (2017). Estimated charter public school enrollment, 2016-2017. http://www.publiccharters.org/publications/estimated-charter-public-school-enrollment-2016-17/

National Association of Charter School Authorizers NACSA (2015) retrived http://www.qualitycharters.org/wp-content/uploads/2015/08/Principles-and-Standards_2015Edition.pdf

Sluder, Thomas, \& Snyder, eds. (2001), Opening and operating charter schools: The Kansas City experience, UCM, Warrensburg, MO.

Thomas, D., \& Machell, J., (2001). Charter schools in Missouri: Central Missouri State University's role in a national movement (1-24), in Sluder, Thomas, \& Snyder (ed.), Opening and operating charter schools: The Kansas City experience, UCM, Warrensburg, MO.

Torres, A.C. (2016). Teacher efficacy and disciplinary expectations in charter schools: Understanding the link to teachers' career decisions. Journal of School Choices. 10(2), 171-199. doi: 10.1080/15582159.2016.1152528.

Virtue, D. C. (2012). Rethinking charter schools. Middle School Journal, 44(2),5. Retrieved from https://login.cyrano.ucmo.edu/login?url=http://search.proquest.com/docview/1282264445?accounti $\mathrm{d}=6143$

Whitmire, R. (2014). Inside successful district-charter compacts. Education Next, 14(4), 42-48.mRetrieved from https://login.cyrano.ucmo.edu/login?url=http://search.proquest.com/docview/1662044553? accountid $=6143$

Zimmer, R., Gill, B., Attridge, J., \& Obenauf, K. (2014). Charter school authorizers and student achievement. Education Finance and Policy, 9(1), 59-85. Doi-10.1162/edfp_a_00120 